\title{
The Sources of Magic Realism in One Hundred Years of Solitude of Gabriel Garcia Marquez \\ SHAIBAL DeV RoY
}

The story of One Hundred Years of Solitude is abundant with paragraphs narrated in magic realism, combining imagination with the real. Garcia Marquez's ability to encompass all the fairy tale characters and to create a new story that unites the real and the marvelous in a 'real' way makes his work intriguing and genuine. He consciously uses fairy tales, mythology and history in his writings to enchant his readers with the narrative of magic realism.

The aim of this essay is to explore the sources of magic realism in Gabriel Garcia Marquez's One Hundred Years of Solitude and to find out the margin of difference between magic realism and fantasy. For this, I have studied Marquez's biography, an interview with his friend Plinio Apuleyo Mendoza and several studies on his book One Hundred Years of Solitude and tried to search for some of the sources of many magical events in this widely celebrated fiction.

According to Encyclopaedia Britannica:

'Magic realism' is chiefly a Latin-American narrative style. It is characterized by the matter-of-fact inclusions of fantastic or mythical elements into apparently realistic fiction. Although this style is known in the literature of many cultures for many ages, the term 'magic realism' is a relatively recent one, first applied in the 1940s by Cuban novelist Alejo Carpentier. Many scholars argue that magic realism is a natural outcome of postcolonial writing, which must make sense of at least two separate realities - the reality of the conquerors as well as that of the conquered. So, features of postcolonial socio-economic set up are quite common to find out in magic realism. However, there are also 
numerous examples of passages containing magic realism without postcolonial elements. (magic realism)

Prominent among the Latin-American magic realists are the Colombian Gabriel Garcia Marquez, the Brazilian Jorge Amado, the Argentines Jorge Luis Borges and Julio Cortazar, and the Chilean Isabel Allende.

In Europe, the term 'magic realism' is applied to explain the tendency among fiction writers - including Franz Kafka, John Fowles and Gunter Grass - to interweave elements of the fantastic and surreal into their otherwise realistic prose. By the mid-1960s, this thrilling stylistic development became a trademark of Latin America's "new novelists" and of the "boom," the term used to describe the sudden international success of Julio Cortazar, Jose Donoso, Carlos Fuentes, Mario Vargas Llosa, and Gabriel Garcia Marquez. Among them, no writer was more famous as an exponent of 'magic realism' than Gabriel Garcia Marquez.

Marquez's childhood contributed profusely in the use of magic realism in his novels, especially, in One Hundred Years of Solitude. Gabriel Garcia Marquez asserts that there's not a single line in his novels which is not based on reality. We cannot help accepting it. At the same time, readers want to explore the sources of his exquisite magic realism. Some references are available in his biography. First, we can consider a celebrated interview of the writer. He says in a conversation with his friend Plinio Apuleyo Mendoza (an interview, later published as The Fragrance of Guava):

I was brought up by a grandmother and numerous aunts who all showered me with attention, and by maids who gave me many very happy childhood moments because their prejudices, while not fewer than those of the women in the family, were at least different. The woman who taught me to read was very beautiful and graceful and I used to like going to school just so I could see her. [Women] find their way more easily, with fewer navigational aids. ... They make me feel secure. 
Thus, we come to know the sources of so many magnificent and exemplary passages of magic realism concerning female characters of Buendia family in One Hundred Years of Solitude. For the first time, through this interview, we get a window open to look into the sources of his 'magic realism'.

Elsewhere, in the same conversation, he says: "My grandmother ... used to tell me about the most atrocious things without turning a hair . . . I realized that it was her impassive manner and her wealth of images that made her stories so credible. I wrote One Hundred Years of Solitude using my grandmother's method." That method involves a carefully designed credulity, which makes readers believe the story without questioning, and Garcia Marquez adopted it from the examples of his grandmother and Franz Kafka.

In One Hundred Years of Solitude, we get a passage narrating the first experience of the protagonists with ice and echoing the events of Garcia Marquez's childhood as put up by Mendoza:

For other writers, I think, a book is born out of an idea, a concept. I always start with an image. ... When I was a very small boy in Aracataca, my grandfather took me to the circus to see a dromedary. Another day, when I told him I hadn't seen the ice on show, he took me to the banana company's settlement, asked them to open a crate of frozen mullet and made me put my hand in. The whole of One Hundred Years of Solitude began with that one image.

We see, Jose Arcadio Buendia, in that passage, put his hand on the ice and held it there for several minutes as his heart filled with fear and jubilation at the contact with that mysterious thing. Being overwhelmed, he paid more so that his sons could have that phenomenal experience. Though little Jose Arcadio refused to touch it, Aureliano touched it and withdrew his hand immediately. But his father paid no attention to him. Intoxicated by the evidence of the miracle, he paid another five reales and with his hand on the cake, as if giving testimony on the Holy Scriptures, he exclaimed, "This is the great invention of our time" (Marquez, One Hundred 18). 
From the same interview we come to know that the bizarre incidents in One Hundred Years of Solitude like, "Remedios the Beautiful ascends to heaven", "Yellow butterflies flutter around Mauricio Babilonia" etc. are all 'based on fact'. For instance, for Mauricio Babilonia, Garcia Marquez explains that when he was about five, an electrician used to come to their house in Aracataca to change the meter. According to Marquez, on one of these occasions, he found his grandmother trying to shoo away a butterfly with a duster, saying, "Whenever this man comes to the house, that yellow butterfly follows him." That was Mauricio Babilonia in embryo. Regarding Remedios the Beautiful, he gives out that he had originally planned to make her disappear while in the house embroidering with Rebecca and Amaranta. But this almost cinematographic trick did not seem viable to him. Then he thought of making her ascend to heaven, body and soul. What is the fact behind it? He answered that it was a woman whose granddaughter had run away from home in the early hours of the morning, and who tried to hide the fact by putting the word around that she had gone up to heaven.

Apart from his colorful childhood memories, Marquez is hugely indebted to the socio-political history of Colombia for his magnificent samples of magic realism in One Hundred Years of Solitude. For example, the civil war between the Liberals and the Conservatives in the story directly echoes events similar to the historical events of Colombia. Michael Wood, in his book Gabriel Garcia Marquez: One Hundred Years of Solitude, says, "Colombia has a long tradition of democracy. The Liberals and the Conservatives, who dominated nineteenth and most of twentieth century politics, stood for quite different things - reform or reaction, free trade or protection, separation or conjunction of church and state; and slowly turned into a rather narrow band of class interests"(8). There is another shrewd and funny reference to this state of affairs in a discussion of the game of checkers in the novel. Jose Arcadio Buendia does not want to play with the priest, Father Nicanor, because he cannot see the point of a contest in which the adversaries are in agreement on principles. Father Nicanor, who has never thought of the game in this light, cannot bring himself to 
play any more. This implies that much fighting in the world concerns anything but principles, which are either agreed or irrelevant. For instance, Colonel Aureliano Buendia discovers that both Liberals and Conservatives are battling solely for power, and are ready to sacrifice any major points of principle in order to achieve it.

We can say a huge extent of Colombian history gets into One Hundred Years of Solitude: the arguments over reform in the 19th century, the arrival of the railway, the War of the Thousand Days, the American fruit company, the cinema, the automobile, and the massacre of striking plantation workers in 1928. The most striking fact of modern Colombian history, known simply as the Violence, gets indirect expression in One Hundred Years of Solitude through guerillas, gangsters, self-defence groups, the police, the army, and the death of some 200,000 people. Even when it was said to be over, or under control, in 1962, there were still 200 civilians dying per month. The Violence was inescapable for the Colombians, and it provoked a flood of fiction, and Garcia Marquez himself addresses it directly in No one Writes to the Colonel and In Evil Hour. However, the Violence appears in One Hundred Years of Solitude indirectly as the massacre of striking workers, ". . . which was sparked off by the assassination of Jorge Eliecer Gaitan, who made his political fame by investigating the 1928 strike. The event was violent enough and could stand as a compression and anticipation of the later phenomenon, an allusion and a synecdoche" (Wood 10). Garcia Marquez ruminates in his autobiography Living to Tell the Tale while visiting his birth place in Aracata:

It was there, my mother told me that day, where in 1928 the army killed an undetermined number of banana workers. I knew the event as if I had lived it, having heard it recounted and repeated a thousand times by my grandfather from the time I had a memory: the soldier reading the decree by which the striking laborers were declared a gang of lawbreakers; the three thousand men, women, and children motionless under the savage sun after the officer gave them five minutes to evacuate the square; the order to fire, the clattering machine 
guns spitting in white-hot bursts, the crowd trapped by panic as it was cut down, little by little, by the methodical, insatiable scissors of the shrapnel. (14-15)

Based on this tragic historical event, a magnificent passage of magic realism is created by Garcia Marquez in One Hundred Years of Solitude:

It was as if the machine guns had been loaded with caps, because their panting rattle could be heard and their incandescent spitting could be seen, but not the slightest reaction was perceived, not a cry, not even a sigh among the compact crowd that seemed petrified by an instantaneous invulnerability. . . . the panic became a dragon's tail as one compact wave ran against another which was moving in the opposite direction, toward the other dragon's tail in the street across the way, where the machine guns were also firing without cease. They were penned in, swirling about in a gigantic whirlwind that little by little was being reduced to its epicenter as the edges were systematically being cut off all around like an onion being peeled by the insatiable and methodical shears of the machine guns. (311)

In the novel, there are also references to the events, such as the discoveries of a suit of rusty armour with calcified skeleton as well as "an enormous Spanish galleon"; and a bloody civil war (12). All of them have a real life testimony based on Colombian history. The armour is said to be from the fifteenth century, which it could just be, since the northeastern coastal region of South America, what is now Colombia and Venezuela, was first visited by the Europeans, with and without armour, in 1499-1500 (Wood 27). So, the time span of the novel can be 'several centuries' later than the sixteenth and some 'three hundred years' since Drakes incursions into the Spanish Main (Marquez 19). In the same way, originally a Colombian civil war ends with the Treaty of Neerlandia (Marquez, One Hundred 174), which was originally signed in 1902.

If we investigate into the name 'Macondo', we can easily understand how Colombian history and Marquez's personal life experience mounted 
into the beautiful use of 'magic realism' in One Hundred Years of Solitude. In Northern Colombia, there is an 'ancient city' called Riohacha. Macondo is the name of a banana plantation near Aracataca, Garcia Marquez's birth place, which is now internationally famous as the name of a mythical community, and obviously, it is due to the fame of One Hundred Years of Solitude. Careful readers can easily understand that the geography and history of two 'Macondo' are not different and the imagined world of 'Macondo' has a real situation in time and space.

In this connection, we can consider the description of Garcia Marquez regarding 'Macondo' in his autobiography Living to Tell the Tale while he was going to visit his grandparents' house:

The train stopped at a station that had no town, and a short while later it passed the only banana plantation along the route that had its name written over the gate: Macondo. This word had attracted my attention ever since the first trips with my grandfather, but I discovered only as an adult that I liked its poetic resonance. I never heard anyone say it and did not even ask myself what it meant. I had already used it in three books as the name of an imaginary town when I happened to read in an encyclopedia that it is a tropical tree resembling the ceiba, that it produces no flower or fruit, and that its light, porous wood is used for making canoes and carving cooking implements. Later, I discovered in the Encyclopaedia Britannica that in Tanganyika there is a nomadic people called the Makonde, and I thought this might be the origin of the word. (19)

Thus, we can easily see through his 'magic realism' to find out its substantial source. In a word, Colombia in One Hundred Years of Solitude becomes a generic and celebrated Latin America, a place of innocence, isolation and magic, of high mountains, rainy tropics and ash-coloured sea. However, internal wars, bureaucrats, booms, strikes, North American interventions and military rulers are also there. It is a sub-continent presented as carefully suspended between myth and history, and it proves 
how extensively Garcia Marquez mingled his real life experience with his fictions to mould the effects of magic realism.

Last but not the least, Marquez's extensive reading of the classics, such as, the Bible, Don Quixote and the works of Virginia Woolf, George Bernard Shaw, Franz Kafka, William Faulkner and Hemingway formulates the other sources. The first and foremost as used by Gabriel Garcia Marquez in One Hundred Years of Solitude is the Bible. Jose Arcadio Buendia, with whom our story begins and is described as a young patriarch, can be compared with Adam, since he is the first citizen of a sort of paradise. Thus, much of One Hundred Years of Solitude reads like a fable. From the start the tiny settlement of Macondo is offered to us as a version of Eden. "The world" we read "was so recent that many things lacked names, and in order to indicate them it was necessary to point." The polished stones in the clear river are "white and enormous, like prehistoric eggs" (1). Here, we can refer to the extract, which Gabriel Garcia Marquez mentioned in his autobiography Living to Tell the Tale. While describing his grandparents' old house in Aracataca, he wrote, ". . . a good place to live where everybody knew everybody else, located on the banks of a river of transparent water that raced over a bed of polished stones as huge and white as prehistoric eggs"(5). Conscious readers can easily discover the similarities of the ideas and dictions. There is another Biblical reference in One Hundred Years of Solitude, which confirms Marquez's indebtedness to the Bible, in which we come to know that the founders of Macondo have traveled to a "land no one had promised them" (31).

In relation to his being influenced by Franz Kafka, Garcia Marquez himself said in his interview with Plinio Apuleyo Mendoza, namely, The Fragrance of Guava: Conversation with Gabriel Garcia Marquez:

Kafka recounted things the same way my grandmother used to. When I read Metamorphosis, at seventeen, I realized I could be a writer. . . . I remember the first sentence, 'When Gregor Samsa woke up one morning from unsettling dreams, he found himself changed in his bed 
into a monstrous vermin.' I said to myself, 'My grandmother used to talk like that. I didn't know you could do this, but if you can, I'm certainly interested in writing.'

If we consider Cervantes' Don Quixote, in many aspects, the patriarch of the novel Jose Arcadio Buendia can be termed as a modern Don Quixote. Particularly, Jose Arcadio Buendia's wonder at the ice and his brilliant personal discovery of the earth's roundness are both, in a sense, jokes on him and are like Don Quixote's courage when faced with lions which will not fight him. Obviously, the lions are hungry and dangerous, but at that moment, they were not in the mood of fighting. So, Quixote's quite genuine courage remains untested: "his folly is heroic, but his heroism looks foolish" (Wood 32), like Sergius' cavalry charge in Arms and the Man by George Bernard Shaw. In the same way, Jose Arcadio Buendia's intelligence and imagination are astonishing but oddly situated, and his simplicity brings about further twist to the story.

Another writer Garcia Marquez is indebted to is Virginia Woolf. Garcia Marquez himself says about the writing of the last part of his novel that his own sense of time was 'completely transformed' by a sentence in Virginia Woolf's Mrs Dalloway, read when he was twenty. "I saw in a flash the whole process of decomposition of Macondo and its final destiny" (Wood 50-51). The extract in question is:

But there could be no doubt that greatness . . . was passing, hidden, down Bond Street, removed only by a hand's-breadth from ordinary people who might now, for the first time and last, be within speaking distance of the majesty of England, of the enduring symbol of the state which will be known to curious antiquaries, sifting the ruins of time, when London is a grass-grown path and all those hurrying along the pavement this Wednesday morning are but bones with a few wedding rings mixed up in their dust and the gold stoppings of innumerable decayed teeth. (Woolf 19-20) 
With One Hundred Years of Solitude in mind, we can see the connections: a secret-guessed and missed, close by and far away, the sudden sense of a later time full of relics of what is now the present, the imagination of different events as if they all "coexisted in one instant" (Marquez 421). For a direct comparison we can quote from One Hundred Years of Solitude:

Sir Francis Drake had attacked Riohacha only so that [Aureliano and Amaranta Ursula] could seek each other through the most intricate labyrinths of blood until they would engender the mythological animal that was to bring the line to an end. Macondo was already a fearful whirlwind of dust and rubble being spun about by the wrath of the biblical hurricane ... for it was foreseen that the city of mirrors (or mirages) would be wiped out by the wind and exiled from the memory of men at the precise moment when Aureliano Babilonia would finish deciphering the parchments, and that everything written on them was unrepeatable since time immemorial and forever more, because races condemned to one hundred years of solitude did not have a second opportunity on earth. (422)

When Garcia Marquez insists that everything in his novel is 'based on reality', he seems in practice to mean two things. First, that the most fantastic things have actually been believed or asserted by living people somewhere, and often in Latin America. "This doesn't mean these things are true but it may make them real" (Wood 56). Garcia Marquez, to describe incidents, as we have already discussed, the yellow butterflies trailing after one of his characters and Remedios, the beauty, taking off into the sky and getting vanished, borrows some dizzying pretext as his fictional reality and then puts the literal truth into his novel as an idle, misplaced speculation. The quite ordinary thus becomes fantastic. Secondly, 'based on reality' means genuinely in touch with some fact of feeling, however hyperbolically and metaphorically expressed. When Jose Arcadio Buendia dies, a rain of tiny yellow flowers falls on Macondo, a 'silent storm' which covers the roofs, carpets the streets and suffocates the animals. This is a miracle even in 'Macondo' - the bits and pieces of legend 
for the end of a legendary character (Marquez, One Hundred 144). But the miracle affords the truth of a fitting image, the appropriateness of the imagination's rising to the grand occasion, as we feel nature ought to, but usually does not. Thus, we see how the real life experiences mould Marquez's narrative style of magic realism.

So, we can conclude, Gabriel Garcia Marquez borrows details from his own life as well as phrases and characters from other writers. It is not to say that history and fiction are the same, but that the border is very marginal. Gabriel Garcia Marquez is not an author with godlike ability of creation; he is the recreating novelist, a possible refiner of nostalgia into lasting work of literature repairing a broken memory with his 'magic realism'. He reaches us with the news of the 'wiped out' Macondo, 'city of mirrors (or mirages)', home and archetype of real facts delivered to non-belief.

\section{Works Cited}

"magic realism." Encyclopaedia Britannica 2009 Ultimate Reference Suite. Chicago: Encyclopædia Britannica, 2009. CD-ROM.

Marquez, Gabriel Garcia. One Hundred Years of Solitude. Trans. Gregory Rabassa. New York: Harper \& Row, 1970. Print.

- - -. Living to Tell the Tale. Trans. Edith Grossman. London: Random House, 2003. Print.

Mendoza, Plinio Apuleyo. The Fragrance of Guava: Conversation with Gabriel Garcia Marquez. London: Faber \& Faber, 1988. n. pag. Web. 02 July. 2012. $<$ http:/ / www.ranadasgupta. com/notes.asp?note_id=52>

Wood, Michael. Gabriel Garcia Marquez: One Hundred Years of Solitude. Cambridge: Cambridge University Press, 1990. Print.

Woolf, Virginia. Mrs Dalloway. London: CRW Publishing Limited, 2003. Print. 